\title{
Saudade do Céu Sobre o rumor da transcendência na poesia de Guilherme de Faria
}

\author{
José Rui Teixeira
}

Universidade Católica Portuguesa (UCP).

\section{Resumo}

Guilherme de Faria (1907-1929) é um poeta neorromântico português que, tendo posto fim à sua vida com apenas 21 anos, deixou uma obra impressiva, de um lirismo elegíaco que dialoga intimamente com a morte. A saudade de Deus - o rumor da transcendência na sua poesia - assenta, fundamentalmente, na ideia da redenção. Talvez diante de uma vida que não reconhecia como sua e que suportava como um exílio, Guilherme de Faria só pudesse desejar a morte e esperar o perdão de Deus. Tendo em consideração a sua vida e a sua poesia, o seu suicídio não é apenas um sintoma de resignação, o resultado de uma insuportável astenia física e moral, mas também uma poderosa expressão de fé na misericórdia de Deus e um profundo desejo de redenção.

Palavras-chave: Poesia; Transcendência; Saudade; Elegia; Suicídio.

\section{Heaven Nostalgia}

On Transcendence Rumor in Guilherme de Faria's Poetry

\begin{abstract}
Guilherme de Faria (1907-1929) is a Portuguese neo-romantic poet who, having ended his life at just 21 years old, left an impressive work, of an elegiac lyricism that intimately dialogues with death. The longing for God - the rumor of transcendence in his poetry - is based, fundamentally, on the idea of redemption. Perhaps in the face of a life he did not recognize as his own and which he endured as an exile, Guilherme de Faria could only wish for death and hope for God's forgiveness. In view of his life and poetry, his suicide is not only a symptom of resignation, the result of unbearable physical and moral asthenia, but also a powerful expression of faith in God's mercy and a deep desire to redemption.
\end{abstract}

Keywords: Poetry; Transcendence; Saudade; Elegy; Suicide. 


\section{Anhelo por el cielo Sobre el rumor de trascendencia en la poesía de Guilherme de Faria}

\section{Resumen}

Guilherme de Faria (1907-1929) es un poeta neorromántico portugués que, habiendo terminado su vida con tan solo 21 años, dejó una obra impresionante, de un lirismo elegíaco que dialoga íntimamente con la muerte. El anhelo de Dios - rumor de trascendencia en su poesía - se basa, fundamentalmente, en la idea de redención. Quizás ante una vida que no reconoció como propia y que soportó como un exiliado, Guilherme de Faria sólo pudo desear la muerte y esperar el perdón de Dios. A la vista de su vida y poesía, su suicidio no es solo un síntoma de resignación, fruto de una astenia física y moral insoportable, sino también una poderosa expresión de fe en la misericordia de Dios y un profundo deseo de redención.

Palabras clave: Poesía; Trascendencia; Desaparecido; Elegía; Suicidio.

\section{Um rapaz raro ${ }^{1}$}

Guilherme de Faria nasceu no dia 6 de outubro de 1907, em Guimarães (no Largo de S. Francisco, freguesia de S. Sebastião). Foi o quinto filho de António Baptista Leite de Faria e de Lúcia Eduarda Pessanha de Sequeira Braga. Guilherme de Faria foi batizado no dia 13 de outubro de 1907, na Igreja Paroquial de S. Sebastião.

A sua infância foi passada em Guimarães. Para além de algumas fotografias, resta-nos uma interessante descrição do P. ${ }^{\mathrm{e}}$ José Carlos Simões, jesuíta que foi seu professor na Escola Académica: Guilherme era um rapaz «mexido e turbulento, de corpo franzino, olhos vivos e ardentes, ligeiramente estrábicos, que varavam, através dos vidros duns grandes óculos, a alma das pessoas, procurando penetrar no íntimo de cada um» (1941, p. 69).

A família vivia, então, no n. ${ }^{\circ} 145$ da Rua de Santo António, quase em frente ao edifício onde estava instalada a Escola Académica. Guilherme, "quando encontrava uma aberta na vigilância da mãe, fugia da casa dos pais para a convivência com os padres da Escola. [...] Aí se matriculou depois, na Instrução Primária, onde já frequentavam o curso liceal os seus irmãos mais velhos" (SIMÕES, 1941, p. 69).

Mas, como realça o P. José Carlos Simões, as lições não o preocupavam demasiadamente. Era então aluno semi-interno.

\footnotetext{
1 Inspirado no título O rapaz raro - iluminações e poemas, de Rimbaud, tradução de Maria Gabriela Llansol (Lisboa, Relógio D’Água, 1999).
} 
No ano letivo de 1917-18, frequenta o 1. ${ }^{\circ}$ ano no Liceu de Martins Sarmento. Não tinha ainda onze anos e, vencendo todas as dificuldades e oposições, funda um quinzenário "Defensor da Causa Sidonista": o 5 de Dezembro, cujo primeiro número data de 22 de agosto de 1918 e o último de 12 de janeiro de 1919, pouco depois do assassinato de Sidónio Pais.

De acordo com o testemunho do P. José Carlos Simões, foi “ainda estudante em Guimarães que ensaiou os primeiros voos na poesia” (1941, p. 71). Porém, datam de 1920 os mais antigos poemas manuscritos encontrados no espólio do poeta. E um testemunho de Lopes Correia sugere que foi com doze anos, já em Lisboa, na convalescença de uma febre tifoide, que Guilherme de Faria escreveu os primeiros versos ${ }^{2}$.

Foi em outubro de 1919 que a família se mudou para Lisboa, instalando-se num amplo e acolhedor 2. ${ }^{\circ}$ andar do n. 11 da Rua da Horta Seca, junto ao Largo de Camões, que correspondia a um andar do antigo palácio de Vanzeller.

No ano letivo de 1921-22, no Liceu Passos Manuel, Guilherme de Faria teve como companheiros António Hartwich Nunes e João da Câmara. Foi nesse período que, aconselhado por Alfredo Pimenta, o jovem poeta preparou a edição de Poemas, o seu primeiro livro, que seria impresso em abril de 1922.

Em outubro inscreve-se no Liceu Pedro Nunes, onde conhece Manuel de Castro e Joaquim Paço d'Arcos, que escreve o seguinte testemunho: Guilherme era, com 15 anos, "um rapaz extremamente precoce. De altura menos que meã, uma forte cabeleira negra, olhos muito negros e vivos por detrás de umas lentes fortes que não lhe ofuscavam, todavia, o brilho" (1971, p. 332).

E se em Guimarães as lições não o preocupavam demasiadamente, em Lisboa, como aluno, Guilherme "não prestava a menor atenção à matéria dos estudos nem fazia qualquer esforço para a fixar” (PAÇO D’ARCOS, 1971, p. 332). Afirmado como poeta, desinteressara-se totalmente dos estudos e refugiava-se no Jardim da Estrela, onde recitava sonetos de Antero de Quental, poemas de Gomes Leal e poesias suas. "Trazia já uma grande bagagem literária e era ela, e o sonho indefinido, que lhe povoavam a mente" (PAÇO D’ARCOS, 1971, p. 332). Em novembro desse mesmo ano de 1922, Guilherme de Faria publica o seu segundo livro: Mais Poemas.

\footnotetext{
Um manuscrito de Guilherme de Faria, datado de outubro de 1920, posteriormente intitulado "Agonia", tem a indicação: "Primeiros versos". Um outro, intitulado "Aspiração", tem acrescentado em post-scriptum: "Escrito numa noite d'insónias, no período duma violenta febre tifoide". Mas o documento mais antigo data de setembro de 1920, onde se encontram manuscritos três poemas (escritos certamente nas férias de verão, na Casa da Burnaria, em Guimarães).
} 
Foi esse um período de intensas amizades, de empenhamento político na causa do Integralismo Lusitano e de importantes leituras que lhe permitirão evoluir de uma poesia muito influenciada pelo espectro romântico e simbolista - de poetas como Antero de Quental, António Nobre, Camilo Pessanha e Eugénio de Castro, entre outros - para uma poesia progressivamente mais próxima da estética neorromântica lusitanista: um lirismo de toada quinhentista, em diálogo com poetas como Afonso Lopes Vieira, António Correia d'Oliveira, Mário Beirão e José Bruges d'Oliveira.

O que aconteceu entre o final de 1922 e o princípio de 1929 é verdadeiramente impressionante: depois de Poemas e Mais Poemas, Guilherme de Faria publica Sombra (1924), Saudade Minha e a plaqueta Oração a Santo António de Lisboa (1926), Destino e Manhã de Nevoeiro (1927); postumamente, em 1929, serão publicados Desencanto e Saudade Minha (poesias escolbidas), antologia editada de acordo com as suas indicações.

Guilherme de Faria deixou organizada uma Antologia de Poesias Religiosas, que só seria publicada em 1947. Foi editor de Teixeira de Pascoaes ${ }^{3}$ e relacionou-se, com mais ou menos proximidade, com as principais figuras das letras e das artes do seu tempo: Raul Brandão, Fausto Guedes Teixeira, Teixeira de Pascoaes, Afonso Lopes Vieira, António Correia d'Oliveira, Alfredo Pimenta, Raul Leal, Luís de Almeida Braga, Carlos de Lemos, Vitoriano Braga, Mário Beirão, Mário Saa, Almada Negreiros, António Botto, José Bruges d'Oliveira, Anrique Paço d'Arcos e António Pedro, entre tantos outros.

No dia 4 de janeiro de 1929, Guilherme de Faria apanhou o comboio na Estação Ferroviária do Cais do Sodré. Tendo chegado a Cascais, remeteu dois bilhetes-postais para o irmão José; seguiu junto ao mar até à Cidadela e, depois, pela Estrada da Boca do Inferno. Foi um caminho sem retorno. Descalço e com um terço de rezar ao pescoço, com apenas 21 anos de idade, Guilherme de Faria precipitou-se no mar. As fragas, a violência das vagas e a água fria reclamaram o seu corpo. Tendo recebido os bilhetes-postais com o carimbo de Cascais, José iniciou as buscas desde a Boca do Inferno, pela volta da Guia, até à Praia do Peixe, em cujo areal o corpo de Guilherme foi encontrado.

Guilherme de Faria foi, em vários sentidos, desconcertante: fracassou nos estudos liceais, mas doutrinou-se com mestres como Afonso Lopes Vieira, António Sardinha e Mário Saa; foi um tradicionalista monárquico, amigo das principais figuras do Integralismo Lusitano, mas também das da Renascença Portuguesa e da Geração de Orpheu.

3 Em 1924 editou Elegia do Amor e, em 1925, três outros livros do poeta de Amarante: Sonetos, Londres e D. Carlos. 
Tudo o que na sua biografia é suscetível de ser relacionado com a sua idade resulta na evidência de uma precocidade impressionante: com apenas 11 anos, ainda em Guimarães, dirigiu um pequeno jornal quinzenário; com 17 anos editou quatro livros de Teixeira de Pascoaes; com 19 anos foi retratado por Almada Negreiros; com 21 anos, aquando da sua morte, tinha uma biblioteca extraordinária - com quase mil volumes - e uma obra poética singular que o integra, no contexto do neorromantismo lusitanista, na melhor tradição lírica e elegíaca da poesia portuguesa.

Mas Guilherme de Faria acabou por ser esquecido, particularmente devido à sua morte tão prematura, às especificidades quase anacrónicas da sua poesia e à proximidade ideológica ao Integralismo Lusitano.

Em 2007, no contexto do centenário do seu nascimento, a sua vida e obra começaram a ser resgatadas dos escombros de quase oito décadas de esquecimento. Com a reedição da antologia Saudade Minha (poesias escolbidas) ${ }^{4}$, a sua poesia foi simbolicamente restituída à história da literatura portuguesa.

\section{Uma terra de poetas e um povo de suicidas}

António José Saraiva escreveu sobre o "novelo afetivo" (1996, p. 85) que caracteriza a "personalidade portuguesa", novelo afetivo que implica - entre outras particularidades idiossincráticas - um certo sentimento de insularidade, o messianismo sebastianista e a saudade, e que aparece "a observadores estrangeiros como desnorteante e paradoxal" (SARAIVA, 1996, p. 84). E esta afirmação transporta-nos para Lisboa, numa tarde de novembro de 1908. Miguel de Unamuno, diante do Convento do Carmo, cujas ruínas góticas sobreviveram ao terramoto de 1755, desabafa: “pensaba qué terremoto íntimo, moral, amenaza este pueblo” (2011, p. 105). Depois compra três diários, lê algumas notícias, percorre as ruas da cidade e escreve:

Entre tanto van y vienen las gentes de esta ciudad cosmopolita; parecen contentas, ríen, gesticulan, acuden a sus negocios o sus distracciones. Y un satisfecho podría decirles al verlas: «Éste es un pueblo como todos los demás; aquí no pasa nada». Y, sin embargo, Portugal, esta misma tierra, es un pueblo triste.

Depois da 1. ${ }^{\text {a }}$ edição, no final de julho de 1929, Saudade Minha (poesias escolbidas) foi reeditada em 2007, com a chancela da Cosmorama Edições (livro reimpresso em 2008). Data de 2013 a 3. ${ }^{a}$ edição. 
Es si, un pueblo triste. $\mathrm{Y}$ de aquí el encanto que para algunos tiene, a pesar de la evidente trivialidad de sus manifestaciones exteriores.

Portugal es un pueblo triste, y lo es hasta cuando sonríe. Su literatura [...] es una literatura triste (UNAMUNO, 2011, p. 106).

O que é que Unamuno viu - pressentiu - nas ruas de Lisboa? O que é que faz deste povo, aos seus olhos, um povo triste mesmo quando sorri? E o que é que faz da sua literatura uma literatura triste? Unamuno vai mais longe e escreve: "Portugal es un pueblo de suicidas, tal vez un pueblo suicida. La vida no tiene para él sentido transcendente. Quiere vivir tal vez, sí, pero ¿para qué? Vale más no vivir" (2011, p. 106).

Aqui nos situamos numa primeira encruzilhada: se, para António José Saraiva, a cultura portuguesa revela algum "desinteresse pela especulação filosófica à ocidental", assim como a "ausência de polémicas teológicas e de doutrinação propriamente mística” (SARAIVA, 1996, 104), para Unamuno, a vida não tem um "sentido transcendente" para o povo português.

Ainda que se trate de afirmações sem excessivas pretensões epistémicas, estamos na presença de observações contundentes sobre um povo que, particularmente desde o século XIV, abdicou da condição europeia que Castela lhe coartava e desenvolveu um certo sentimento de isolamento, porque - entre Portugal e a Europa - Castela funcionou historicamente como um deserto isolador, mais do que um espaço de ressonância e comunicação.

Esse ensimesmamento, simbolicamente, nimba a sua vocação atlântica de uma vertigem suicidária: um povo tão afetivamente apegado às suas raízes, às suas origens, projeta-se numa diáspora que ainda hoje reúne quase um terço dos portugueses. E se esporadicamente buscou em França, sobretudo a partir do século XIX, o lenitivo para um persistente sentimento de orfandade, esse contacto não só não o tornou mais europeu, como acentuou, por cotejamento, a disforia da sua singularidade.

A intelligentsia portuguesa dos séculos XIX e XX escolheu exprimir-se preferencialmente por meio da literatura, absorvendo vastos domínios do pensamento filosófico e teológico, geralmente autónomos e que, em Portugal, se tornaram difusos. Importa referir que no final do século XIX, se a condição de teólogo rareava e se circunscrevia a meios clericais mais ou menos entrincheirados, não existia uma demarcação evidente nem da condição, nem do âmbito da ação dos filósofos e dos políticos; todos, mesmo os homens da ciência, procuravam afirmar-se através do meio literário. Talvez por isso 
Jaime Cortesão tenha escrito, em 1911 - a propósito de Teixeira de Pascoaes -, que "Portugal é uma terra de poetas" (1988, p. 275).

Neste contexto, o caso de Antero de Quental é exemplar: a sua consagração cívica, no contexto da resistência ao Ultimato inglês, em 1890, é uma consequência de uma outra consagração, anterior, significativamente mais profunda: o poeta era considerado um "santo", com um estatuto moral e espiritual que, numa sociedade progressivamente mais secularizada e anticlerical, já não era reconhecido à Igreja. E ao contrário do que se passava em muitos países, onde o herói nacional era geralmente um chefe militar, em Portugal, no centro do culto patriótico estava um poeta.

E não se trata de um caso isolado ou de algo sem precedentes na cultura portuguesa: bastaria termos em consideração o prestígio do reitrovador D. Dinis e de uma figura como a de Camões, a quem cabe - no século XVI - a missão de (re)inventar Portugal em Os Lusíadas, esse livro, o único livro que - nas palavras de Eduardo Lourenço - "não se pode reescrever, pois foi ele que nos fez, tal como a nós mesmos continuamos a sonhar-nos" (1999, p. 154). Não é assim de estranhar que, de Garrett e Herculano a Pascoaes e Pessoa, os poetas sejam reconhecidos como os legítimos representantes do "gênio nacional" (Volkesgeist).

E aqui nos situamos numa segunda encruzilhada: apesar do "desinteresse pela especulação filosófica à ocidental" e da "ausência de polémicas teológicas e de doutrinação propriamente mística», e apesar de, aos olhos de Unamuno, a vida não ter um "sentido transcendente" para este povo, a tendência dominante do pensamento filosófico português, entre a segunda metade do século XIx e a primeira metade do século xx, é precisamente a filosofia da religião, situada no âmbito de uma "meta-religião" 5 , que acaba por ser a expressão da saudade, enquanto nostalgia do absoluto [numa aproximação à Sehnsucht alemã], premente nas formulações do messianismo sebastianista, do Quinto Império e do Encoberto, de Sampaio Bruno a Pessoa, à Era Lusíada e ao saudosismo de Teixeira de Pascoaes.

Compreende-se assim que, em 1922, em Madrid, Leonardo Coimbra tenha afirmado que "a moderna poesia portuguesa é fundamentalmente de ordem religiosa. Representa, desde Antero, por Nobre e Junqueiro, até Pascoaes, uma crise de valores espirituais interpretativos e diretores da Vida" (2009, p. 42).

"Antiteologia” ou “crença substituta", conceitos de George Steiner (2003, p. 13). 
Regressamos a Antero de Quental, porque é precisamente nele que descobrimos "as ruínas e os escombros interiores, a inquietação moral e metafísica, numa reinvenção da missão do poeta” (MENDONÇA, 2001, p. 132). E é isso que faz de Antero, nas palavras de Eduardo Lourenço, "um místico em estado um pouco menos selvagem do que Rimbaud, numa cultura que odeia de instinto o diálogo direto, real ou imaginário, à Bergman, com Deus ou a sua ausência" (1999, p. 43). E, por isso, o seu suicídio "não é uma peripécia subjetiva, nem uma tragédia sentimental ou cultural, à Werther ou Chatterton, é o último ato de uma vida que desejou tocar a face de Deus e não a encontrou" (LOURENÇO, 1999, pp. 43-44).

Antero levou até às últimas consequências aquilo que se pressente em tantos outros poetas portugueses, mesmo naqueles em quem, muitas vezes, a "exploração do desejo e o risco da confissão dão lugar ao tradicionalismo métrico e louvor de um Portugal rural e de um povo crente" (MENDONÇA, 2001, p. 134), como acontece com a generalidade dos poetas neorromânticos.

Uns resilientes, outros dissidentes, entre profissões de fé e apostasias, com mais ou menos intensidade mística, com mais ou menos tragicidade, o que os une é a abertura - tantas vezes agónica - à transcendência, a procura que se desdobra em instantes de perda e abandono.

Entre encontros, desencontros e reencontros, muitos evocam a fé perdida, uma fé puída pelas agruras e vicissitudes da vida. Tal como Antero de Quental ${ }^{6}$, Cesário Verde 7 e António Nobre ${ }^{8}$, Camilo Pessanha procura alhear-se de Deus e lamenta-o, até porque se pressente, implícita na sua poesia, uma profunda tensão espiritual, eivada de uma saudade de si próprio, uma saudade da infância e uma saudade desse Deus que seria lenitivo para o desterro e impediente do afundamento:

Eu mesmo quero a fé, e não a tenho...

- Um resto de batel - quisera um lenho,

Para não afundir na treva imensa,

O Deus, o mesmo Deus que te fez crente...

Nem saibas que esse Deus omnipotente

Foi quem arrebatou a minha crença (1997, p. 193).

\footnotetext{
6 "Deixá-la ir, a alma lastimosa,/ Que perdeu fé e paz e confiança"; "O último lírio, a Fé, secou-se... morre..." (QUENTAL, 2001, p. 251 e 354).

"Nós ignoramos, sem religião,/ Ao rasgarmos caminho, a fé perdida" (VERDE, 2004, p. 124).

"Pedi-te a fé, Senhor! pedi-te a graça,/ mas não te curvas nunca p'ra me ouvir"; "Não creio em nada! e fui tão religioso!” (NOBRE, 2000, p. 383 e 395).
} 
Com efeito, nas antologias de poesia religiosa portuguesa ${ }^{9}$ encontramos menos os pedregosos e íngremes caminhos que alguns poetas percorreram no sentido de perscrutar Deus como interrogação, enquanto abundam exemplos de uma familiaridade inquestionada e autocomprazida, que prescindem das tensões mais profundas da experiência espiritual, como se muitos poetas descansassem "numa cómoda satisfação de conhecer ou de dizer Deus" (MENDONÇA, 2001, p. 134).

\section{Na mão de Deus ${ }^{10}$}

Proveniente de um meio católico tradicional e tendo aderido ao Integralismo Lusitano, para Guilherme de Faria o Catolicismo era fundamentalmente uma expressão sociológica do seu nacionalismo.

Particularmente nos primeiros livros, encontramos as expressões ornamentais de uma religiosidade que não se interroga ainda sobre Deus, nem sobre a condição humana à luz da transcendência, nem sobre um sentido soteriológico da existência. A verdade é que, por muito precoce que Guilherme de Faria tenha sido, não seriam expectáveis tais interrogações num poeta que publica o seu primeiro livro com apenas 14 anos.

Referindo-se a Manhã de Nevoeiro, livro de 1927, Joaquim Paço d'Arcos escreve: "Há no livro a citação do nome de Deus, a evocação da Virgem, mas mais como elementos de composição literária do que como expressões de uma fé que era nele muito débil, ou angustiada na própria compenetração da sua carência" (1971, p. 364).

Não estou certo de que a fé de Guilherme de Faria fosse tão débil como Joaquim Paço d'Arcos afirma e creio que dificilmente perceberemos as interrogações religiosas do poeta se nos limitarmos a procurar as citações do "nome de Deus" ou as evocações da Virgem.

Logo nos cinco poemas que Guilherme de Faria escolhe dos seus dois primeiros livros para a antologia Saudade Minha (poesias escolhidas), encontramos as tendências principais daquilo que, mais do que a expressão da

9 Destaco três antologias: FRIAS, C. (org.), Cem das melhores poesias religiosas da língua portuguesa, Lisboa: Guimarães e C. ${ }^{a}, 1932$; FARIA, G. de (org.), Antologia de poesias religiosas, Lisboa: Edições Gama, 1947; e RÉGIO, J., e SERPA, A., Na mão de Deus: - Antologia de poesia religiosa portuguesa, Lisboa: Portugália Editora, 1958.

10 Soneto de Antero de Quental: "Na mão de Deus, na sua mão direita,/ Descansou afinal meu coração. [...] Dorme o teu sono, coração liberto,/ Dorme na mão de Deus eternamente!" (ANTERO, 2001, p. 313). 
transcendência na sua poesia, podemos designar por lugares transimanentes: 1) a relação entre o amor e a saudade, logo explicitada neste admirável verso: "Amor que, antes de o ser, se fez saudade" (2013, p. 38); 2) a profunda intimidade com a morte; e 3) a vontade de ascender, como se lê no soneto "Crepuscular": "Quem me dera, meu Deus, também morrer/ Para, amanhã, no azul - ressuscitar!” (2013, p. 37).

Em "Súplica", percebemos essa "ânsia eterna de além..." (2013, p. 40); e, no soneto "Subir!", Guilherme de Faria imprime um profundo sentido ascensional à sua poesia: "Quero subir, Senhor! Tenho o direito/ De subir até Vós a alma imortal” (2013, p. 44).

No poema "Eu", de Sombra (1924), o poeta repete as perguntas: "Sou noite? Sou alvorada?/ Vou ascender ou cair?” (2013, p. 48); e lê-se aí esta importante quadra:

Em sonho, fui luz de aurora

No esplendor da Eternidade!

Mas, hoje, a minha alma chora

No desterro da saudade... (2013, p. 49).

E aqui se afirma outra tendência da personalidade e da poesia de Guilherme de Faria: a consciência de que a sua vida é um exílio, um desterro; de que sofre um doloroso desajuste entre o ser e o existir. Esse desajuste assoma impressivamente no poema "Confissão", em que o poeta se dirige à noite:

Tu és a treva eterna e misteriosa,

E eu sou a luz jamais amanhecida:

Sombra de horror, sonâmbula e saudosa

Da luz duma outra vida (2013, p. 51).

Neste poema, mais do que uma fé débil, percebemos um certo ressentimento retórico em relação a Deus - "És a irmã da minha alma, oh pobre, erma roseira/ Que Deus soube criar, mas não deixou florir!” (2013, p. 52) -; e percebemos, ainda assim, a intensidade, o fervor, do seu desejo de ascender a Deus. Trata-se de um poema extraordinário, cujo auge não é o último verso, mas o penúltimo, cabendo ao último a afirmação desolada de um papel existencial que representa e com o qual não se sente identificado. 
Quero ser a canção dos astros e dos céus,

E sentir, na minha alma, a luz de Deus!

$[\cdots]$

E sendo sombra, humana escuridão,

Quero ascender em frémitos de chama,

E ser vida de eterna redenção,

Ser a bênção de amor que o sol derrama!

Ser a névoa dum sonho, a errar, longe de tudo...

Ser a voz da oração, a ânsia dum voo...

- Mas eu quero viver, quero ser tudo,

Só não quero, Senhor!, ser o que sou! (2013, p. 52).

As cartas que escreveu aos amigos mais íntimos confirmam este sentimento de desterro, de exílio existencial ${ }^{11}$, que é recorrente na sua poesia: "absorto num outro que já fui" (2013, p. 53); "Senhor!, eu não sou eu, sou a lembrança/ Dum outro que não fui, mas sonhei ser" (2013, p. 61); "Vai despertando, saudosa,/ Lembranças duma outra vida” (2013, p. 79). E é esse poeta que - no "desterro da memória” (2013, p. 106) - rumoreja a elegia de uma esperança que embala:

E embora eu não as entenda, Vão-me a esperança embalando

Lembranças de não sei onde, Saudades de não sei quando... (2013, p. 171).

11 Como é o caso desta carta, escrita a Manuel de Castro no dia 8 de outubro de 1923, dois dias depois de ter celebrado o 16. ${ }^{\circ}$ aniversário: "Eu tenho sede de vida. Quero viver a minha vida. Estou cansado de monotonia. Tudo, afinal, é sempre o mesmo, o mesmo, o mesmo! E, Manuel, pudesse quebrar a monotonia desta vida! Tenho vivido submerso em mentira! E quero respirar! Tenho sede de ar puro! Estou saturado deste viver infecto e mesquinho, vida de lama, de sordícia e de aquiescência! Um sorriso... outro sorriso; uma frase velha, usada, banal... insignificâncias. Palavras amáveis, palavras gastas e falsas. É tudo assim. Tudo trescala hipocrisia, interesse, miséria. E, Manuel, tenho dezasseis anos e ainda não vivi! Desconheço-me! Se acaso vivo, vivo longe, bem longe do que sou. Porque, tal como sou todos os dias para todos aqueles que conheço (e às vezes, meu Deus, também para mim!), sou outro, bem diferente, sou um estranho, banal como a banalidade, hipócrita como a hipocrisia e boçal como toda a gente. E tenho sede de vida! Vozes vivas de saudade acordam dentro de mim! Vozes da minha saudade... Tenho saudades de mim! Sinto-me farto deste exílio. Vou regressar ao meu Reino! Quero viver!”. 
Em 1926, em Saudade Minha, sente-se já um irreversível desapego em relação à vida ${ }^{12}$. A desilusão e a abulia combinam-se num importante leitmotiv desta poesia, como se percebe em "Saudade" - "Tudo, na vida, morre e tudo passa, Tudo, afinal, numa ilusão consiste" (2013, p. 62) - e, mais ainda, em "De noite":

A vida não é um sonho de ansiedade

Inútil de sofrer,

Que, para além da vida, há uma verdade

- E temos de morrer!

Assim, debaixo da verdade eterna,

Para quê desejar sonhos, ideais?

Sepultados no fundo da caverna,

Esperemos, somente, a luz eterna

Das horas imortais!

Não desejes o sol que reverbera:

Olha, no poente, a fulva luz da aurora...

E fiquemos, assim, meu pobre amor, à espera

Da morte redentora (2013, p. 63).

O poema que melhor traduz esse sentido de desistência abúlica em relação a tudo é "Não vale a pena..." (2013, p. 73) ${ }^{13}$, que marca este livro de 1926, em que o neorromantismo lusitanista de Guilherme de Faria se afirma na intrínseca relação entre o amor, a saudade e a morte ${ }^{14}$. No entanto, não

12 Como em "Elegia" (2013, p. 90): "E assim eu vivo, e me iludo!// - Mas que me importam as penas/ De amor, que me tornam louco,/ - Se a vida é tudo, e só tudo,/ O que, nas horas serenas,/ Nos parece ser tão pouco...".

13 "Viver sentindo n'alma o fogo ardente/ Da mais alta ambição, que nos condena/ A lutar, a sonhar eternamente,/ - Não vale a pena...// Viver na febre intensa dos desejos/ E sonhos da luxúria que envenena/ As almas, ao calor de falsos beijos,/ - Não vale a pena...// Viver cantando, d'alma leda e pura,/ Versos ao som de pastoril avena,/ Longe da vida tão hostil e escura,/ - Não vale a pena...// Viver para o meu Amor - Vida e Doçura! -/ Doce mulher cheia de graça, plena/ Do mais divino amor e formosura,/ - Não vale a pena...// Não vale a pena... É vão todo o desejo./ - E para quê sonhar, nesta amargura,/ Acesa a luz da esperança, que eu não vejo,/ E ter sonhos, quimeras a sorrir,/ - Se, para além da humana desventura,/ Tenho o leito da eterna sepultura,/ Para fechar os olhos e dormir?...".

14 Como em "Exaltação", que é o primeiro poema de Saudade Minha que, na organização da antologia da sua poesia, Guilherme de Faria coloca no final de Sombra (2013, p. 54): "Quem és, Visão de há tanto aparecida/ Na escura solidão, que é a minha sorte? / - És, num sonho de amor, a eterna luz da vida;/És a vida que vai, sonhando, para a morte.// [...] És a bênção de Deus, que exalta e que redime,/ Amor do meu Amor!". E em "Canção" - ibid., p. 78: "No sonho que me domina,/ És como o sol a esplender:/ Saudade, amor, luz divina,/ Por quem eu quero morrer!". 
Sobre o rumor da transcendência na poesia de Guilherme de Faria

perde um soteriológico sentido ascensional, sempre associado à libertação do desterro em que vive. Assim a sua alma, como a água de uma fonte:

Subir a Deus, feita em névoa,

Para em lágrimas descer,

E chorar, sonhar, na terra,

Para, de novo, ascender! (2013, p. 81).

Apaixonado por Emília Castro, irmã do amigo mais próximo, Guilherme de Faria inicia em Saudade Minha um diálogo que só terminará em Desencanto, o seu livro póstumo, impresso um mês após o seu suicídio. Este amor supostamente não correspondido - permite-nos perceber a teia que o poeta urde em torno do sentimento-experiência da saudade. Lê-se em "Elegia":

Tu não pressentes a morte,

Em mistérios envolvida,

Nem a infinita desgraça

De quem, um dia, nasceu...;

E, como vives em graça,

Não tens saudades da vida,

Nem tens saudades do Céu! (2013, p. 63).

A saudade corresponde à fatalidade de quem desgraçadamente nasce desterrado, sempre pressentindo a morte. É o exílio - a consciência do exílio - que traz as saudades dessa vida que o poeta sente não ter vivido, como nos diz na notável "Cantiga" de Manbã de Nevoeiro (1927):

Morrer - não me importa!

Mas devagarinho...

- Que é pena, Senhor!,

Morrer consumido

De pena, somente

Por não ter vivido! (2013, p. 197).

E que traz as saudades do Céu, onde - pela morte redentora - espera encontrar Deus e libertar-se do desterro.

Recordo que António Cândido Franco me interrogou sobre ter sido o amor a causa do suicídio. Respondi-lhe, então, que esse amor que condicionou o seu suicídio, no princípio de 1929, foi o mesmo sentimento 
que o manteve vivo, que lhe deu esperança, que adiou o trágico desfecho. Lê-se em "Destino":

- Assim eu vivo por vós,

E o meu amor não se cansa,

E a cantar-vos, minha voz

Diz a Deus minha esperança!

Depois, à tarde, nos céus,

Surgem estrelas, sorrindo,

E eu adormeço, sentindo

Em mim a graça de Deus.

Nos céus de eterna harmonia,

Sorriem doces promessas

Ao meu viver de agonia!

- Alma, jamais esmoreças,

Esquece as mágoas e a dor,

E, no fim da humana sorte,

Rasga o mistério da Morte,

Sempre a amar o meu Amor! (2013, pp. 91-92).

A relação de Guilherme de Faria com Deus - e com a transcendência - não se pode dissociar do amor, de um amor sublimado. Ocorrem-me as palavras de António José Saraiva:

O amor é um tema extraordinariamente obsessivo na literatura portuguesa [...]. É um sentimento em que certa sensualidade insatisfeita e uma certa espiritualidade impura se temperam mutuamente [...]. Falou-se de uma certa «religião do amor em Portugal» e pode dizer-se que ele é entre nós quase uma forma de misticismo, e de um misticismo que não logra despegar-se inteiramente da carne (1996, p. 84-85).

$\mathrm{Na}$ verdade, dificilmente encontraremos na história da literatura portuguesa um poeta que seja mais consequente com este paradigma da "religião do amor". É inevitável citar aqui, integralmente, o soneto "Redenção", com que termina Saudade Minha:

Alma exilada, e tão cansada e triste,

Num mundo onde ninguém te compreende,

Vai sonhando de amor e, enfim, ascende 
Sobre o rumor da transcendência na poesia de Guilherme de Faria

À luz ideal que, em sonhos, entreviste.

Sonha!, vive do amor que pressentiste Sorrindo à imperfeição de que descende A dor do meu viver e, em mim, ascende

A fé do eterno bem que em Deus existe!

- Porque essa luz divina que entrevejo

No céu que, para além desta amargura,

Eu pressinto, e que surge ao meu desejo

Como a bênção de Deus - no seu esplendor

Que é um sorriso de encanto e de ternura,

Só pode ser, Amor, o teu amor! (2013, p. 95).

Trata-se, efetivamente de uma plataforma transimanente. Essa «religião do amor», em Guilherme de Faria, não é apenas uma obsessão temática, réplica de uma tendência lírica da poesia portuguesa. O primeiro poema de Destino (1927) - "Cântico" - termina assim:

E é por vós, Saudade minha

E meu Sonho alto e divino,

Que eu vejo, acesa nos céus,

A graça do meu Destino:

É por vós que eu creio em Deus! (2013, p. 105).

Quando confrontado com a impossibilidade desse amor, o suicídio do poeta nimbou este último verso de uma verdade impressiva. Não havia, então, nada que pudesse impedir Guilherme de Faria desse caminho sem regresso que terminaria na Boca do Inferno.

Há duas possibilidades de redenção transimanente na vida e na poesia de Guilherme de Faria: o amor e o espírito nacionalista, na senda de um sebastianismo de feição neorromântica lusitanista ${ }^{15}$, no âmbito dos ideais integralistas.

15 Disso são exemplos poemas como "Exaltação" (2013, p. 131), "Destino português" (2013, p. 140), "Poeta" (2013, pp. 166-167) e "Manhã de Nevoeiro" (2013, p. 241): "Manhã de Nevoeiro... A névoa apaga/E cega o meu olhar...// Mas, doce, a minha voz rompe a cantar,/ E sobe, da toada branda e vaga,/ À exaltação da profecia:// A névoa apaga e cega o meu olhar.../ Mas, para além, é o sol dum novo Dia”. 
Guilherme de Faria foi, entre os seus irmãos e amigos, o que mais se implicou no movimento integralista, desdobrando em Lisboa o entusiasmo dos comícios em que, com apenas 10 anos, falava aos companheiros de liceu, em Guimarães ${ }^{16}$.

Curiosamente, a 11 de março de 1923, Alfredo Pimenta apresentou uma moção na assembleia-geral dos sócios das Juventudes Monárquicas Conservadoras, exprimindo o desejo de que o Conselho Superior Político da Causa Monárquica convocasse sem demora o Congresso Monárquico. Esta questão suscitou intervenções de alguns oradores e, segundo Alfredo Pimenta:

Desses oradores, há um que merece referência especial, pois foi uma revelação tribunícia, como já, tempos antes, fora uma revelação poética. Trata-se de um jovem de 15 anos, Guilherme de Faria, estudante e poeta que, falando em nome da mocidade, fez, num discurso cheio de vigor e de notável corte literário, as mais sãs e patrióticas afirmações. Houve um momento em que a assembleia estava positivamente eletrizada pelas palavras do moço orador (1947, pp. 83-84).

Isso mesmo é testemunhado por Caetano Beirão, num interessante artigo publicado em janeiro de $1930^{17}$, e por Aníbal Gomes Contreiras que, no exemplar do seu livro Primeiras Líricas (1920) que ofereceu a Guilherme de Faria, escreve a seguinte dedicatória, com data de 21 de maio de 1923: "Ao jovem poeta e insigne orador máximo da juventude monárquica”.

E apesar do fervor aqui testemunhado, também a sua ação política acarretaria desilusões e Guilherme de Faria foi-se gastando, entre cafés e botequins, prostíbulos e casas de fado. Entre o céu e a terra:

16 Como recorda o P. ${ }^{e}$ José Carlos Simões (1941, p. 71): "O que verdadeiramente o interessava, nesta fase da vida, era comandar soldados, rapazes como ele, de vistosas fardas de papel e que lhe chamavam o Kaiser, nome que lhe não desagradava, e lhe obedeciam cegamente".

17 "A primeira vez que o vi foi numa sessão de propaganda das Juventudes Monárquicas Conservadoras. [...] Junto à mesa dos oradores, um rapazinho muito novo, talvez a pessoa mais nova que estava naquela sala - com um rosto muito expressivo e os olhos a refletir uma alma inquieta e sonhadora $[. .$.$] -, seguia atentamente o que se ia dizendo,$ manifestando uma suficiência grande. Esgotada a lista dos oradores inscritos, vi-o subir ao estrado, pedir a palavra e começar a falar com voz grande e sonora, a revelar uma grande segurança de si e uma grande fé. [...] Pois o jovem sócio das Juventudes dissertou como um orador experimentado. Não falou de votos, nem de eleições; nem pediu a Monarquia para daí a três meses. Falou numa linguagem nova, cheia de misticismo nacionalista e de esperança num Portugal maior. [...] Acabou o seu discurso num belo cântico de patriotismo, de ardor e de fé que arrebatou a assembleia" (BEIRÃO, 1930, p. 3). 
Assim, à noite, escutando,

Entre guitarras plangendo,

A voz do fado subindo,

O Povo, triste e cismando,

Vai seu mal adormecendo,

Num sonho distante e lindo... (2013, p. 139).

E entre a terra e o céu:

Nas altas chamas erguida,

Já paira e fulge nos céus,

A noite da nossa vida

Sempre ascendendo p'ra Deus! (2013, p. 159).

As "saudades do Céu"18 só tornavam mais presente a morte, mais próximo o fim. O leitmotiv do sono abúlico ${ }^{19}$ torna-se, progressivamente - no interior do sistema semântico constituído pelo amor, pela saudade e pela morte -, o âmago da sua poesia. O poema "Desolação" não deixa quaisquer dúvidas:

Oh Morte escura, nesta ansiedade,

Tão só no mundo, já sem o abrigo,

Dum vago sonho, duma saudade,

Sonho contigo.

Cheio de mágoas, apenas vejo

Mágoas e luto, por toda a parte...

- Ah, vem, oh Morte, que, assim, desejo

Talvez, amar-te.

18 "Senhor!, quem sou eu/ Que sinto, nesta alma,/ Saudades do Céu?// E a noite da Morte/ De estrelas se alumbra,/ De eterno esplendor.../ E eu morro, sonhando/ Que a Morte deslumbra,/ Eu morro de amor...» $(2013,1975)$. «Chuva, lenta, caía;/ E lentamente a cair,/ Fria, fria,/ Parecia já sentir/ Saudades donde caía.// A água clara e ribeirinha/ Que vem de longe, correndo,/ E para o rio caminha,/ Parece que vem dizendo,/ A suspirar: - “Também eu,/ Tão cansada e pobrezinha,/ Tenho saudades do céu!” (2013, 191).

19 Entre tantos outros poemas, destaco aqui um dos mais impressivos poemas de Guilherme de Faria: "Fim" (2013, p. 177) e "A tua voz" (2013, pp. 200-201), que termina assim: "Que esta canção peregrina/ Hei de ouvi-la a vida inteira...// Que há de embalar minha sorte/ Esta canção que não finda;/ E, doce, mais doce ainda,/ Adormecer-me na Morte...// E quando a hora soar,/ Da alma, enfim redimida,/ Ascender à eterna Vida,/ Será tua voz saudosa/ - Voz de graça milagrosa! - / A que virá despertar/ A minha alma adormecida,/ A sonhar". 
Vem! - que o meu sonho de primavera, O amor, a graça que o céu me deu, Em fria cinza de vã quimera, Tudo morreu!

Ai, vida minha, luz dos meus olhos, Não mais te quero sonhar, nem ver! E vem, oh Morte, fechar-me os olhos, Para esquecer (2013, p. 153).

Num monólogo dramático, sucedem-se alguns poemas de Desencanto (1929), livro póstumo de Guilherme de Faria. Com apenas 21 anos, mas desencantado da vida, já sem esperança, este jovem poeta interroga a sua condição e a morte afigura-se-lhe como a única possibilidade de redenção.

Do teu cansaço e tua dor, descansa!

É neste brando enlevo que eu te quero,

Sorrindo ao fumo duma nova esperança

Como à ilusão dum novo desespero (2013, p. 219).

Súmula do taedium vitae, desse spleen em que imergiram languidamente tantos dos poetas que mais o inspiraram, estes versos são a expressão de uma astenia incurável, que resulta na desistência, na renúncia, no abandono. Em 1928, Guilherme de Faria está convencido de que são vãs todas as lutas e ilusões. Antero de Quental foi, no final do século XIX, o mais representativo vate deste desencanto, desta cedência ao sono abúlico.

Vários poetas românticos e neorromânticos, de tendência marcadamente elegíaca e noturna, fazem deste leitmotiv uma caixa de ressonância para as suas vozes poéticas. Também Fernando Pessoa, no seu Livro do Desassossego:

Sinto-me às vezes tocado, não sei porquê, de um prenúncio de morte. $\mathrm{Ou}$ seja uma vaga doença, que se não materializa em dor e por isso tende a espiritualizar-se em fim, ou seja um cansaço que quer um sono tão profundo que o dormir lhe não basta - o certo é que sinto como se, no fim de um piorar de doente, por fim largasse sem violência ou saudade as mãos débeis de sobre a colcha sentida (PESSOA, 2013, p. 66).

Guilherme de Faria, parece pacificado: 
Sobre o rumor da transcendência na poesia de Guilherme de Faria

Fumo evanescente

Duma vã quimera,

Mas por quem esta alma,

Ainda e sempre, espera!

- Onde existes, graça

Da mais linda sorte?

- És, talvez, mentira!

Mas esta alma ansiosa

Que por ti suspira,

Pois que soube amar-te,

Quer desencantar-te,

E é por ti que vive,

Morta de ansiedade,

E é por ti que morre,

Louca de temor!

- Ai, Saudade minha,

Paz consoladora,

És talvez a Morte,

Mas jamais o Amor! (2013, pp. 247-248).

No fim de «Esparsa», percebemos que Guilherme de Faria cede ao sono, abandona-se, aparentemente sem paroxismos nem exasperações:

- Dormir... dormir... dormir...

Eu quero só dormir...

- Não mais sonhar e amar!

Não mais sentir, sofrer

A pena de esperar!

Não mais, sequer, erguer,

Num vago e triste olhar,

A última esperança

Ao ermo azul dos céus...

- Na Morte, enfim, descansa,

Oh dúvida de Deus! (2013, pp. 223-224).

Em O Mito de Sísifo, Albert Camus afirma que "só há um problema filosófico verdadeiramente sério: é o suicídio” (2005, p. 15). Dietrich Bonhoeffer 
considera o suicídio "a última e extrema autojustificação do homem como homem” (2006, p. 166). Para o teólogo alemão, a verdadeira causa do suicídio «não é o desespero, em que quase sempre se realiza este ato, mas a liberdade do homem também a braços com o desespero de se autojustificar do modo mais elevado. Se o homem não consegue justificar-se mediante a felicidade e o êxito, pode ao menos fazê-lo no seu desespero» (2006, p. 166).

Se relativizarmos as especificidades do seu contexto, o suicídio de Guilherme de Faria como que sacramentaliza a sua necessidade de conferir um derradeiro sentido humano a uma vida tornada humanamente desprovida de sentido. Como escreveu Bonhoeffer, "o sentimento espontâneo de horror que se apossa de nós frente à realidade do suicídio não depende do carácter reprovável de semelhante ato, mas da sua tremenda solidão e liberdade" (2006, pp. 166-167).

A verdade da relação de Guilherme de Faria com Deus - com a transcendência - assenta, fundamentalmente, na ideia da redenção. Talvez a sua fé não fosse tão débil como pensava Joaquim Paço d'Arcos; talvez diante de uma vida que não reconhecia como sua e que suportava como um exílio, Guilherme de Faria só pudesse desejar a morte e esperar o perdão de Deus. $\mathrm{Na}$ verdade, tendo em consideração a sua vida e a sua poesia, o suicídio de Guilherme de Faria não é apenas um sintoma de resignação, o resultado de uma insuportável astenia física e moral, mas também uma poderosa expressão de fé na misericórdia de Deus e um profundo desejo de redenção:

Visão do eterno bem, sonho infinito

De eterna luz e extático fulgor,

Acende em mim a graça e resplendor

Do teu supremo ideal de amor bendito.

Se, na humana expiação, blasfemo e grito,

Perdoa e dá-me a fé no teu alvor,

Porque, só de sonhá-lo, neste horror,

Sinto ascender a Deus meu ser aflito.

E quando a vida escura e dolorosa

Passar, desfeita em névoas de ilusão,

Ante o frio da Morte misteriosa,

- Oh piedosa e sagrada Aparição! -

Doira a minha alma com a luz radiosa

Do teu olhar de bênção e perdão! (2013, p. 74). 
Sobre o rumor da transcendência na poesia de Guilherme de Faria

\section{Referências}

BEIRÃO, C., "Como conheci Guilherme de Faria", in O Marcoense (Marco de Canavezes), 25 de janeiro de 1930.

BONHOEFFER, D., Ética, Lisboa: Assírio \& Alvim, 2006.

CAMUS, A., O Mito de Sísifo, Lisboa: Livros do Brasil, 2005.

COIMBRA, L., "Sobre la moderna poesía portuguesa", in Obras Completas V (1922-1923) (tomo I), Lisboa: IN-CM, 2009.

CORREIA, L., "Dois anos depois - Guilherme de Faria", in Ação (Coimbra), janeiro de 1931.

CORTESÃO, J., "O poeta Teixeira de Pascoaes", in Teixeira de Pascoaes, A Saudade e o Saudosismo, Lisboa: Assírio \& Alvim, 1988.

FARIA, G. de (org.), Antologia de Poesias Religiosas, Lisboa: Edições Gama, 1947.

FARIA, G. de, Saudade Minha (poesias escolhidas), Maia: Cosmorama Edições, 2013.

FRIAS, C. de Frias, Antologia de poesias religiosas, Lisboa: Guimarães e C. ${ }^{2}, 1932$

LOUREnÇO, E., Portugal como Destino seguido de Mitologia da Saudade, Lisboa: Gradiva, 1999.

MENDONÇA, J. T. e VALE, P. P., "Literatura religiosa. Época contemporânea”, in Carlos Moreira Azevedo (dir.), Dicionário de História Religiosa de Portugal (vol. J-P), Lisboa: Círculo de Leitores, 2001.

NANCY, J.-L., Las Musas, Buenos Aires: Amorrortu Editores, 2008.

NOBre, A., Poesia Completa, Lisboa: Publicações Dom Quixote, 2000.

PAÇO D'ARCOS, J., "Destino e Obra do Poeta Guilherme de Faria", in Pedras à Beira da Estrada (vol. II), Lisboa: Guimarães Editores, 1971.

PESSANHA, C., Clepsidra e outros poemas, Porto, Lello Editores, 1997.

PESSOA, F., Livro do Desassossego, Lisboa: Assírio \& Alvim, 2013.

PIMENTA, A., Cartas Monárquicas, Porto: Livraria Civilização, 1947.

QUEIRÓS, E. de, «Um génio que era um santo», in Antero de Quental: In memoriam, Porto: Mathieu Lugan - Editor, 1896.

QUental, A. de, Poesia Completa, Lisboa: Publicações Dom Quixote, 2001.

RÉGIO, J. e SERPA, A. de, Na mão de Deus: Antologia de poesia religiosa portuguesa, Lisboa: Portugália Editora, 1958.

SARAIVA, A. J., A Cultura em Portugal: Teoria e História (vol. I), Lisboa: Gradiva, 1996.

SIMÕES, J. C., "Um antigo aluno - O Poeta Guilherme de Faria", in O Liceu de Guimarães (Guimarães), Ano II, 1941.

STEINER, G., Nostalgia do Absoluto, Lisboa: Relógio D’Água, 2003. 
TEIXEIRA, J. R., Vida e obra de Guilherme de Faria: Os versos de luz por escrever, Maia: Cosmorama Edições, 2013.

TEIXEIRA, J. R., Vestigia Dei: uma leitura teotopológica da literatura portuguesa, Maia: Cosmorama Edições, 2019.

Unamuno, M. de, "Un pueblo suicida", in Por tierras de Portugal y de España, Madrid: Alianza Editorial, 2011.

VERDE, C., O Livro de Cesário Verde, Lisboa: Assírio \& Alvim, 2004.

ZAHONERO, L. A., El lugar de los poetas: Un ensayo sobre estética y política, Madrid: Ediciones Akal, 2017.

Submetido em: 19-10-2020

Aceito em: 26-11-2020 